\title{
MEMBANGUN SERVER MULTICAST BERBASIS STREAMING MENGGUNAKAN CENTOS
}

\author{
Irwan Susanto, ${ }^{1} \sim$ Rizky Junita Sari $\mathrm{H}^{2}$ \\ Program Studi Diploma III Teknik Telekomunikasi, Purwokerto \\ irwansusanto_yk@yahoo.com, ci_quyuzz@yahoo.co.id
}

\begin{abstract}
The development of IP-based technology contribute to the development of telecomunication and information technology. One of IP-based technology application is streaming multicast, as part of broadcasting. The streaming process is made by accessing Telkom-2 broadcast through AKATEL LAN network, then server forward it to clients using multicast IP system. Multicast IP is D-class IP, which is able to send data package in realtime. In multicast system, server only send one data package to some clients with same speed transmition. The Telkom-2 broadcast is already accessed before sent as data package. Server will access Telkom-2 broadcast using parabola antenna and Hughes modem, then forward it to clients through AKATEL LAN network. Clients must conect to server via AKATEL LAN network and already instaled VLC player, in order to be able to access the Telkom-2 broadcast .
\end{abstract}

Keywords: server, client, multicast, streaming

\section{PENDAHULUAN}

Seiring pesatnya perkembangan jaringan komputer. Teknologi yang saling menghubungkan komputer di dunia memungkinkan untuk dapat saling bertukar informasi dan data, bahkan dapat saling berkomunikasi dan bertukar informasi berupa gambar atau video. Perkembangan jaringan komputer yang semakin pesat memungkinkan proses melewatkan trafik video atau audio secara langsung. Proses ini biasa disebut dengan streaming.

Pada jaringan komputer, metode pengiriman paket data secara umum dibedakan menjadi 4 yaitu :

- Anycast adalah sebuah metode pengiriman data dimana data dikirimkan pada lokasi yang terdekat atau pada jalur terbaik yang dilihat oleh sistem.

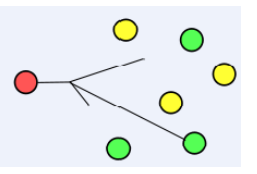

\section{Gambar 1.1 Anycast}

- Unicast adalah sebuah metode pengiriman data dimana data dikirimkan pada satu lokasi yang jelas, dan setiap lokasi yang menerima kemudian mengirimkan laporan penerimaan kepada pengirim. Disini, kualitas pengiriman data dapat dijamin, karena setiap kegagalan pengiriman akan diketahui oleh pengirim dan dapat melakukan pengiriman ulang. Sistem inilah yang secara umum digunakan pada sistem jaringan komputer saat ini.

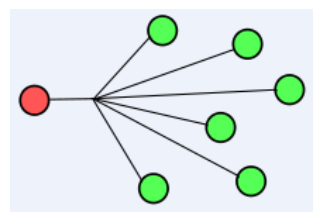

Gambar 1.2 Unicast

- Broadcast adalah sebuah metode pengiriman data, dimana data dikirimkan ke banyak titik sekaligus, tanpa melakukan pengecekan apakah titik tersebut siap atau tidak, atau tanpa memperhatikan apakah data itu sampai atau tidak. Salah satu contoh penggunaan sistem ini adalah siaran televisi dan radio. Dimana stasiun siaran melakukan siaran terus menerus tanpa mempedulikan apakah ada pesawat televisi ataupun radio yang memonitor siaran tersebut. 


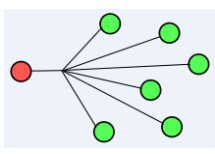

Gambar 1.3 Broadcast

- Multicast adalah dimana data dikirimkan kepada banyak titik sekaligus, dengan titik tujuan dikelompokkan berdasarkan groupgroup tertentu melalui alamat groupnya. Hal ini akan mengakibatkan pengiriman menjadi lebih efektif dibandingkan broadcast dan dapat terhubung ke client lebih banyak dibandingkan sistem unicast.

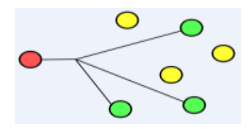

Gambar 1.4 Multicast

Multicast adalah jaringan yang relatif untuk menangani metode penyampaian informasi ke sekelompok tujuan dibandingkan metode pegiriman paket data yang lain, dan pada multicast setiap penerima akan mendapatkan streaming yang sama.

Untuk melakukan pemrosesan dan melayani semua terminal/client tersebut ada sebuah server sebagai pusat pemroses dan didalamnya didukung sistem operasi. Dan sistem operasi yang mendukung mesin tersebut ada banyak, tetapi yang lebih populer dan gratis adalah sistem operasi Linux.

CentOS kependekan dari Community Enterprise Operating System adalah sistem operasi bebas yang didasarkan pada Red Hat Enterprise Linux (RHEL) yang merupakan salah satu keluarga dari Linux Maka penulis mencoba menggunakan sistem operasi CentOS.

\section{Rumusan Masalah}

Berdasarkan uraian di atas terdapat beberapa permasalahan yang perlu dikaji lebih lanjut, yaitu:
1. Bagaimana membangun server multicast dari sisi server yang menggunakan sistem operasi CentOS?

2. Bagaimana mengkonfigurasi dari sisi client agar mendapatkan streaming dari server yang menggunakan sistem operasi CentOS?

\section{Batasan Masalah}

Batasan masalah dalam peneltian ini adalah sebagai berikut :

1. Tidak membahas secara detail perangkat- perangkat pendukung.

2. Memanfaatkan jaringan komputer Local Area Network (LAN) yang sudah ada

3. Hanya membahas konfigurasi streaming video disisi server yang meggunakan system operasi CentOS

\section{Tujuan}

Tujuan dari penelitian ini :

1. Membangun server multicast.

2. Mengetahui konfigurasi streaming dari server yang menggunakan sistem operasi CentOS sampai ke client dengan memanfaatkan jaringan komputer Local Area Network (LAN).

\section{Manfaat}

Manfaat penelitian ini adalah :

1. Dapat menambah pengetahuan tentang streaming Centos dan perangkat- perangkat pendukung lainnya seperti, Modem,VideoLAN Client (VLC).

2. Streaming video disisi server diharapkan dapat diaplikasikan sebagai fasilitas tambahan disebuah warnet atau jaringan komputer LAN lainnya.

\section{METODE PENELITIAN}

Metode penelitian yang digunakan dalam penelitian ini adalah eksperimental, yaitu dengan melakukan ujicoba membangun 
server dengan sistem operasi CentOS dan konfigurasi client.

1. Instrumen Penelitian

Instrument penelitian yang digunakan

: Operating System CentOS sebagai server, Personal Computer sebagai server-client dengan software VideoLAN Client (VLC),Local Area Network (LAN). Berikut adalah spesifikasi komputer yang digunakan : Pentium Celeron $2.80 \mathrm{GHz}, 512$ MB RAM,VGA 32 MB,60 Gb Harddisk,Sistem operasi CentOs pada server, Sistem operasi Windows XP pada client,DirectX 9.0c, Audio Card.

2. Metode Analisa

Pada penelitian ini, peneliti melakukan analisa dengan mengamati sinyal hasil streaming hingga didapatkan sinyal paling maksimal

3. Rencana Kerja

Rancangan rencana kerja penelitian ini tampak dalam gambar 1.5.

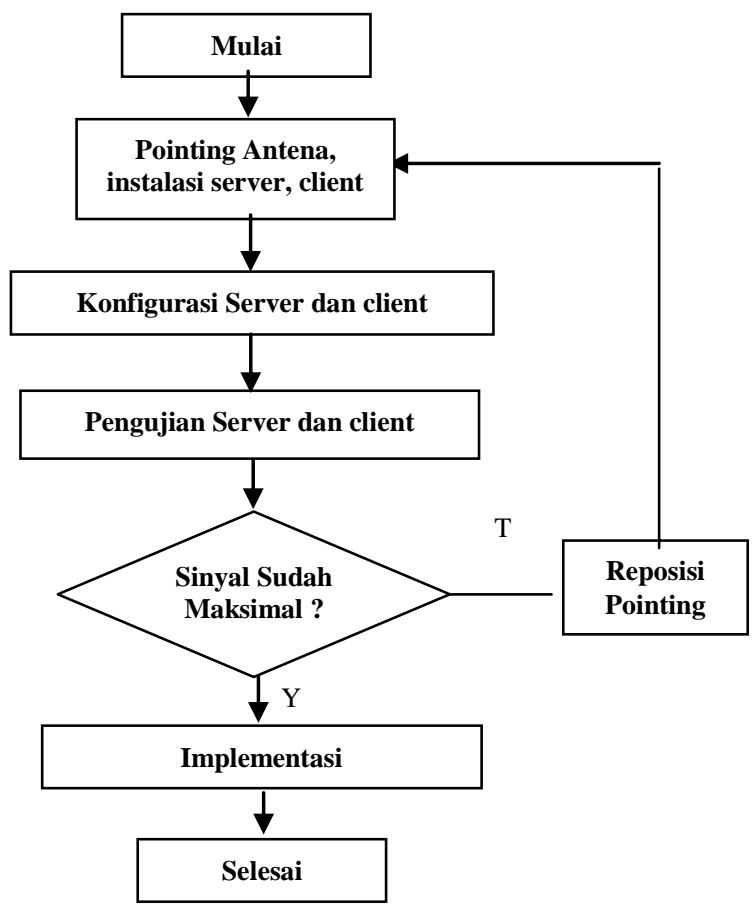

Gambar 1.5 Flow Chart Recana Kerja

\section{DASAR TEORI}

\section{A. Streaming}

Streaming adalah sebuah teknologi untuk memainkan file video atau audio secara langsung ataupun dengan pre-recorded melalui server. File video atau audio yang terletak pada server dapat secara langsung dijalankan pada komputer client sesaat setelah ada permintaan dari users sehingga proses download yang menghabiskan waktu cukup lama dapat dihindari ${ }^{[4]}$.

Saat file video atau audio di stream maka akan terbentuk sebuah buffer dikomputer client dan data video atau audio tersebut akan di download ke dalam buffer yang telah terbentuk pada client. Dalam waktu beberapa detik, buffer telah terisi penuh dan secara otomatis file video atau audio akan dijalankan oleh sistem. Sistem akan membaca informasi dari buffer sambil tetap melalukan proses download file sehingga tetap berlangsung di client. Delay waktu sebelum file video atau audio dijalankan antara 10-30 detik ${ }^{[5]}$.

Video atau audio dapat di encode untuk keperluan komunikasi secara real time atau dapat juga di pre-encoded dan disimpan dalam format DVD (Digital Versatile Disc) atau Video-CD (Compact Disc) untuk dijalankan pada saat dibutuhkan. Preencoded video memiliki keuntungan yaitu tidak memerlukan encoding secara real time. Namun pre-encoded video ini memiliki keterbatasan fleksibilitas, yaitu tidak dapat beradaptasi secara signifikan pada kondisi kanal yang berbeda ${ }^{[5]}$.

Ide dasar dari video streaming ini adalah membagi paket video ke dalam beberapa bagian, mentrans-misikan paket tersebut, kemudian penerima (receiver) dapat men-decode dan memainkan potongan paket file video tanpa harus menunggu seluruh file terkirim ke me penerima. Secara konsep, proses streaming dibagi menjadi tiga tahap, yaitu $^{[8]}$ :

1. Membagi data video/audio yang telah terkompresi menjadi paket-paket data.

2. Pengiriman paket-paket data video/audio.

3. Penerima (receiver) mulai mendecode dan menjalankan video/audio walaupun paket data yang lain masih dalam proses pengiriman ke mesin PC. 


\section{B. Jaringan Komputer}

Jenis koneksi pada jaringan terbagi beberapa macam :

1. Local Area Network (LAN) adalah sejumlah komputer yang saling dihubungkan bersama dalam satu area tertentu yang memiliki area cukup luas, seperti di dalam satu kantor atau gedung. Secara garis besar terdapat dua tipe jaringan LAN, yaitu jaringan Peer to Peer dan jaringan ClientServer. Pada jaringan peer to peer, setiap komputer yang terhubung ke jaringan dapat bertindak baik sebagai workstation maupun server. Sedangkan pada jaringan ClientServer, hanya satu komputer yang bertugas sebagai server dan komputer lain berperan sebagai workstation.

2. Metropolitan Area Network (MAN)

Metropolitan Area Network (MAN), pada dasarnya merupakan versi LAN yang berukuran lebih besar dan biasanya menggunakan teknologi yang sama dengan LAN. MAN dapat mencakup kantor-kantor perusahaan yang letaknya berdekatan atau juga sebuah kota dan dapat dimanfaatkan untuk keperluan pribadi (swasta) atau umum. MAN mampu menunjang data dan suara, bahkan dapat berhubungan dengan jaringan televisi kabel.

\section{Wide Area Network (WAN)}

Wide Area Network (WAN), jangkauannya mencakup daerah geografis yang luas, seringkali mencakup sebuah negara bahkan benua. WAN terdiri dari kumpulan mesin-mesin yang bertujuan untuk menjalankan program-program (aplikasi) pemakai.

\section{Sistem Operasi CENTOS}

CentOS kependekan dari Community Enterprise Operating System adalah sistem operasi bebas yang didasarkan pada Red Hat Enterprise Linux (RHEL) yang merupakan salah satu keluarga dari Linux ${ }^{[4]}$. CentOS bisa didapatkan dengan mendownload.

\section{VLC Media Player}

Video Lan Client (VLC) media player adalah sebuah software aplikasi yang diperuntungkan bagi streaming video. VLC dapat digunakan untuk memutar file dengan format MPEG, VCD, DVD, TV channel, dan lain-lain. VLC dapat digunakan sebagai client untuk mengakses video yang di-stream dari server. Video Lan Client (VLC) media player dapat berjalan di berbagai sistem operasi, seperti Window, Linux, Mac OS, dan sistem operasi lainnya.

\section{a. Satelit Telkom-2}

Satelit Telkom-2 merupakan satelit yang dirancang untuk menyediakan area telekomunikasi Indonesia yang terletak pada $118^{\circ}$ Bujur Timur, dibuat oleh Orbital Sciences Corp diluncurkan pada tanggal 16 November 2005 di Kourou Prancis kota Guiana. Kapasitas satelit adalah 24 transponder C-band dan massa satelit 1190 Kg. ${ }^{[5]}$ Penguat yang digunakan pada setiap transponder adalah TWTA (Traveling Wave Tube Amplifier). Band frekuensi sinyal uplink payload satelit adalah 5,925 GHz$6,425 \mathrm{GHz}$ sedangkan downlink satelit sebesar $3.7 \mathrm{GHz}-4.2 \mathrm{GHz}$.

Daya jangkaunya mencapai seluruh ASEAN, India dan Guam. Telkom-2 memiliki life time selama 15 tahun. Telkom2 dikendalikan oleh Stasiun Pengendali Utama (SPU) Cibinong yang terletak pada $6.44773^{\circ} \quad$ (lattitude) dan $106.93613^{\circ}$ (longitude). Satelit ini diharapkan akan mendukung sistem komunikasi transmisi back bone yang meliputi layanan telekomunikasi Sambungan Langsung Jarak Jauh (SLJJ), Sambungan Langsung Internasional (SLI), internet, dan jaringan komunikasi untuk kepentingan militer.

Satelit terbagi menjadi dua komponen utama yaitu Payload (Comunication Subsystem) dan Bus. Payload adalah subsystem yang berhubungan dengan komunikasi 24 transponder yang terdapat dalam satelit sedangkan bus adalah subsystem satelit yang berfungsi untuk mengoperasikan, melakukan perawatan, serta penanggulangan gangguan/anomali yang terjadi pada satelit. Satelit Telkom-2 mempunyai jenis satelit three axis body stabilized yang akan mengontrol posisi satelit dengan tiga sumbu koordinat yaitu $x, y, z$. Sumbu $x$ merupakan sikap satelit saat berputar ke arah depan/pergerakan ke selatan (roll), sumbu $y$ merupakan sikap satelit saat bergerak/berputar arah kiri atau ke 
kanan/pergerakan ke arah barat (pitch), dan sumbu $z$ menunjukkan sikap satelit saat berputar/bergerak $360^{\circ}$ (yaw).

\section{E. Pointing Antena}

Diketahui bahwa satelit berada pada orbit geostationer tampak relatife tetap apabila dilihat dari bumi. Oleh karena itu apabila stasiun bumi berada di daerah cakupan satelit, maka dapat saling berkomunikasi dengan cara mengarahkan antena pengirim atau penerima ke satelit dengan posisi yang tepat.

Posisi stasiun bumi baik stasiun bumi pemancar ataupun penerima memegang peranan penting dalam komunikasi satelit. Sedangkan satelit hanya berperan sebagai pengulang (repeater) untuk itu stasiun bumi harus diletakan pada posisi yang tepat dan berada pada daerah cakupan satelit agar sinyal yang dikirim dapat diterima satelit dan dipancarkan kembali pada stasiun penerima. Untuk meletakkan stasiun bumi pada posisi yang tepat agar bisa berkomunikasi dengan satelit, harus diketahui sudut elevasi-nya. Karena sudut elevasi merupakan sudut yang dihasilkan oleh arah utara sebenarnya dari titik yang akan dipasang antena dengan arah vertikal antara satelit dengan antena. Untuk sudut azimuth A teoritis berada diantara $0^{\circ}$ dan $360^{\circ}$. Sudut azimuth didapat dengan rumus sebagai berikut ${ }^{[10]}$ :

$\mathrm{A}=\tan ^{-1}\left[\frac{\tan \mid \text { longSB }- \text { longSat } \mid}{\sin \text { lat } S B}\right]$

dimana: A':sudutpositifuntukmenghitungA SB : Stasiun Bumi

A : Azimuth

Sudut Elevasi didapat dengan rumus ${ }^{[8]}$ :

$\cos \theta=\left(R_{E}+h\right) \sqrt{\frac{1-\cos ^{2} \varphi_{g} \cos ^{2} \Delta \lambda}{h^{2}+2 R_{E}\left(R_{E}+h\right)\left(1-\cos \varphi_{G} \cos \Delta \lambda\right.}}$

$\mathrm{E}=\operatorname{Cos}^{-1} \theta$

dimana :

E : sudut elevasi

$\mathrm{h}$ : tinggi satelit dari permukaan bumi (35786 $\mathrm{Km})$

Re : Jari-jari Bumi (6378 Km)

$\operatorname{Cos} \varphi$ :selisih longitude stasiun bumi dengan satelit $\cos \Delta$ : nilai latitude dari stasiun bumi

\section{POINTING DAN INSTALASI}

A. Pointing Antena

Langkah-langkah pointing antena untuk modem Hughes adalah sebagai berikut :

1. Mengatur rangkaian Laptop, modem dan parabola.

2. Memasukkan kabel UTP pada Laptop

3. Memasukkan kabel koaksial pada LNB parabola

4. Memasukkan kabel koaksial dan kabel UTP dari parabola ke modem.

5. Melakukan setting ethernet LAN laptop dengan IP Address 192.168.0.2 subnet mask 255.255.255.252 atau menggunakan DHCP.

6. Melakukan percobaan koneksi keperangkat modem Hughes dengan menggunakan command prompt. Mengetikkan ping 192.168.0.1

7. Mengetik telnet 192.168.0.1 1953 untuk melakukan konfigurasi modem.

8. Memilih option 'a' dan ' $\mathrm{i}$ ' untuk melakukan instalasi modem, kemudian memilih yang ' $\mathrm{a}$ ' yaitu antena pointing receiver.

9. Melakukan pointing antena dan mengarahkan antena ke satelit TELKOM2. Sampai mendapatkan nilai SQF (Signal Quality Factor) $>80$.

\section{B. Instalasi Server}

Server yang di uji coba diinstal menggunakan sistem operasi Centos. Langkah-langkah menginstalasi sebagai berikut :

1. Memasukkan CD instalasi sistem operasi CentOS pada komputer server.

2. Menekan enter satu kali, kemudian menunggu sebentar saat server melakukan booting dari $\mathrm{CD}$.

3. Memilih tombol skip untuk melewati bagian pengecekan $\mathrm{CD}$ dan langsung melakukan instalasi.

4. Pada tampilan bahasa dan pengaturan keyboard pilih yang US English. Kemudian pilih next.

5. Memilih instal CENTOS, lalu next.

6. Pada tampilan Partisi Data, memilih hapus partisi pada linux. Delete semua partisi yang ada. Memilih new.

7. Memilih add partition. 
8. Pada partition dibagi menjadi 3 bagian adalah :

Mount Point : dikosongkan

File system: swap

Size : $2000 \mathrm{MB}$

Mount Point : / boot

File system : ext 3

Size : $1000 \mathrm{MB}$

Mount Point : / (untuk root)

File system : ext

Size : $10000 \mathrm{MB}$

9. Memilih next untuk melanjutkan partition data, maka akan muncul kotak perintah 'Apakah anda yakin melakukan partition data?' Memilih yes.

10. Memilih jaringan IPV4 dan Dynamic IP Configuration (DHCP). Memilih next.

11. Setelah instalasi selesai maka server telah terpasang sistem operasi CentOS.

\section{Instalasi Client}

Pada sisi client diinstal software Video LAN Client (VLC) yang akan digunakan untuk mendapatkan streaming dari server menuju client. Berikut ini langkah-langakah proses instalasi Video LAN Client (VLC):

1. Langkah awal adalah harus memiliki software Video LAN Client tersebut dengan cara dapat mendownload di internet pada situs berikut :

http://mirrors.ircam.fr/pub/videol an/vlc/0.8.6d/win $32 / v l c-0.8 .6 \mathrm{~d}$ win32.exe

2. Setelah mendownload software tersebut kita mulai dapat melakukan instalasi

3. Memilih next maka muncul sebuah surat perizinan melakukan instalasi software Video LAN Client (VLC), memilih I Agree yang berarti saya setuju.

4. Pemilihan komponen dimana Video LAN Client akan di instalasi. Memilih Start Menu dan Desktop Shortcut, lalu next

5. Menyimpan file yang ada di Video LAN Client disini ditempatakan pada 'Disk $C^{\prime}$. Memilih install

6. Setelah itu maka VLC sedang di proses penginstalasian.

7. Instalasi telah selesai kemudian memilih Finish

\section{KONFIGURASI}

\section{A. Konfigurasi Server}

Server adalah sebuah komputer yang menyediakan file, sumberdaya atau layanan yang tertentu yang diperlukan dalam sebuah jaringan. Dalam hal ini pengkonfigurasian server dimaksudkan agar server yang digunakan dapat mengirimkan data berupa audio dan video yang kemudian diteruskan ke client. Adapun langkah pertama adalah setting IP Address masing-masing yang terhubung ke server multicast sebagai berikut

- IP Address eth0 pada server harus satu subnet dengan IP Address pada modem interface eth0

- IP Address eth1 pada server harus satu subnet dengan IP Address pada client

- IP Address Modem Satelite adalah 10.230.75.1

- IP Address Server eth0 adalah 10.230.75.2

- IP Address Server eth1 adalah 192.168.0.156

- IP Address Client adalah 192.168.0.0/5

- Setting IP masing-masing interface dengan cara mengetikan perintah

- \#vi/etc/sysconfig/networkscript/ifcfg-eth0

- \#vi/etc/sysconfig/networkscript/ifcfg-eth1

- Melakukan setting IP masing-masing interface, kemudian melakukan bridge atau jembatan untuk menghubungkan antara masing-masing ethernet dengan modem, dengan melakukan perintah berikut ini : \#brctl addbr br0

- Melakukan perintah untuk memasukkan interface ke bridge atau jembatan dengan perintah : \# brctl addif br0 eth0 dan \#brctl addif br0 eth1.

- Melakukan interface bridge kemudian menghidupkan dan memberi IP Address bridge dimana IP Address interface tidak boleh sama dengan IP Address yang berada di LAN, tapi interface bridge ini masih dalam satu jaringan dengan LAN yang sama. Langkah tersebut dilakukan dengan cara mengetikan perintah seperti dibawah ini : \#ifconfig br0 up dan \#ifconfig br0 192.168.0.121

- Tambahkan juga perintah routing table nya, dengan route baru dengan 
mengetikkan perintah seperti dibawah ini : \#route add-net 224.0.0.0/4 gw 10.230.75.1

- Aktifkan forward dengan mengedit file scripts yang telah ada dengan perintah berikut sehingga terdapat basis sebegai berikut :\#etc/ sysconfig/network dan FORW ARD_IPV4=true

- Apabila tidak sesuai dengan basis berikut maka dapat mengedit file yang telah ada dan hanya mengubah nilai false menjadi true. Dengan mengetik perintah berikut ini :\#/etc/sysctl.conf dan net.ipv4forward=1

- Melakukan pengecekan apakah forward sudah berhasil atau belum dan nilainya harus 1 (satu). Dengan mengetikan perintah berikut ini :\#cat /proc/sys/net/ipv4/ip_forward

- Jika belum melakukan restart terhadap konfigurasi tersebut dengan mengetikan perintah berikut ini :\#/etc/init.d/network restart

- Melakukan pengecekan ulang dengan mengetikkan perintah berikut ini : \#cat /proc/sys/net/ipv4/ip_forward

- Apabila telah berhasil maka dapat melakukan pengecekan paket yang masuk ke server multicast dengan mengetikan perintah berikut ini : tcpdump -ni eth0

- Apabila belum berhasil, maka mencoba cek pada bagian firewall nya dengan mengetikan perintah berikut ini :\#iptables $-\mathrm{L}$

- Menghapus isi yang ada pada firewall, coba flush firewall dengan perintah berikut ini : \#iptables-F

\section{B. Konfigurasi Client}

Pengertian secara sederhana, client adalah komputer yang bukan server. Jika server menyediakan file, sumber daya, layanan tertentu, maka client adalah komputer yang meminta file, sumber daya, atau layanan dari server. Dalam penelitian ini, client ditugaskan untuk menerima streaming dari server, sehingga pada sisi client ini perlu diinstal software VLC media player.

Video Lan Client (VLC) media player adalah sebuah software aplikasi yang diperuntukan bagi streaming video. VLC dapat digunakan untuk memutar file dengan format MPEG, VCD, DVD, TV channel, dan lain-lain. VLC dapat digunakan sebagai client untuk mengakses video yang di-stream dari server.

Video Lan Client (VLC) media player dapat berjalan di berbagai sistem operasi, seperti Windows, Linux, Mac OS, dan sistem operasi lainnya.

Langkah-langkah mengoperasikan Video Lan Client (VLC) media player adalah sebagai berikut :

1. Membuka VLC media player yang digunakan untuk pengetesan video streaming.

2. Membuka File-Open Network Stream,

3. Memilih UPD/RTP Multicast, kemudain masukkan address multicast 239.0.220.1 dan port isi dengan 1234.

4. Memilih OK, maka akan muncul video yang di streamingkan lewat address tersebut.

\section{PENGUJIAN}

\section{Pengujian Pada sisi Modem}

Pada saat melakukan pengujian disisi modem, status modem dinyatakan berhasil apabila nilai SQF (Signal Quality Factor) yang didapat pada saat melakukan pointing antena melampui angka $80(>80)$, apabila belum tercapai maka perlu dilakukan pointing ulang antena dengan merubah posisi azimuth, elevasi dan memutar feedhorn.

\section{Pengujian Pada sisi Server}

Pada saat melakukan pengujian disisi server, server dinyatakan berhasil apabila server sudah dapat menstreamingkan siaran dari satelit Telkom-2. Siaran tersebut kemudian dikirimkan ke client, apabila client tidak dapat menerima siaran yang ada pada server, maka server dianggap tidak berhasil. Untuk mengetahui server sudah menerima paket data yang dikirim satelit Telkom-2 dapat mengetikkan 
perintah pada konfigurasi server dengan cara sebagai berikut : tcpdump -ni eth0.

\section{Pengujian Pada sisi Client}

Pengujian pada sisi client dapat dilakukan bilamana sudah terinstalasi software VLC media player, yang nantinya bertugas untuk memutar file video atau audio yang ada pada server multicast. Pengujian client dikatakan berhasil apabila sudah menerima streaming dari server.

\section{Pengujian pada sisi Jaringan}

Pengujian pada sisi jaringan dilakukan terhadap jaringan LAN AKATEL yang dipakai dalam penelitian ini yaitu Laboratorium Komputer-1. Pada saat melakukan pengujian pada sisi jaringan ternyata jam kesibukan jaringan memberikan kontribusi pengaruh terhadap hasil streaming. Jaringan yang ada di Laboratorium Komputer-1 AKATEL mengalami trafik yang padat atau sibuk disekitar jam 11.00 siang sampai dengan 03.00 siang, pada jam 07.00 pagi sampai dengan 10.00 pagi hasilnya bagus.

\section{PEMBAHASAN}

Satelit, parabola, modem, server dan client saling terkait dan berhubungan. Dimana satelit yang digunakan adalah satelit Telkom-2 yang berada pada posisi 118 BT. Satelit ini lah yang memberikan siaran, yang kemudian ditangkap oleh parabola kemudian diterima oleh modem yang berfungsi sebagai Digital Satellite Receiver lalu diteruskan ke server dan diterima oleh client.

Parabola yang digunakan adalah parabola satu LNB untuk mengangkap siaran satelit Telkom-2. Agar parabola dapat mengarahkan pada posisi satelit Telkom-2, yang perlu diatur adalah sudut azimuth, elevasi dan memutar feedhornnya. Posisi antena parabola yang dimiliki AKATEL berada pada posisi 109,14BT dan 7,25LS. Agar parabola mendapatkan arah satelit yang sesuai perlu dilakukan perhitungan sudut azimuth dan elevasi. Dari hasil perhitungan maka kedua sudut tersebut adalah 50,99 untuk azimuthnya dan $76,53^{\circ}$ untuk elevasinya.
Siaran satelit Telkom-2 diterima oleh modem, modem yang digunakan adalah modem Hughes HN7000 Series yang berfungsi sebagai Satellite Digital Receiver. Modem yang akan berperan penting dalam hasil streaming multicast. Dari modem inilah bisa mengetahui nilai SQF (Signal Quality Factor) yang didapat dengan mengubah azimuth, elevasi dan memutar feedhorn.

Server disini bertugas sebagai penerima paket data yang dikirimkan oleh satelit, parabola, dan modem. Server akan menstreamingkan ke sisi client. Untuk mengetahui server sudah berhasil dan dapat menerima paket data dengan mengetikkan perintah "tcpdum -ni eth0".

Client disini bertugas sebagai penerima hasil streaming yang dikirimkan oleh server. Disisi client sudah terinstal sebuah software VLC media player untuk dapat melihat siaran yang ada pada satelit Telkom-2. Apabila pada sisi client tidak mendapatkan siaran yang ada pada satelit Telkom-2, maka harus melakukan pengecekan ulang pada sisi antena dengan cara melakukan pointing ulang sampai nilai SQF (Signal Quality Factor) $>80$, apabila nilai $\mathrm{SQF}>80$ maka pengecekan ulang disisi server dengan cara mengetikan perintah "tcpdump -ni eth0" apabila sudah menerima paket data yang diterima oleh modem yang dikirimkan maka server dalam kondisi baik atau berhasil, maka melakukan pengecekan ulang pada sisi jaringan dimana jaringan sangat berpengaruh pada hasil streaming yang baik, dengan cara melihat sinyal jaringan yang didapat oleh client dalam kondisi yang "strenght" atau kuat. Apabila pada sisi jaringan kondisi sinyal "strenght" atau kuat, client sudah dapat menerima hasil streaming yang baik yang dikirimkan oleh server, dan client sudah dapat menikmati streaming multicast.

Hasil pengamatan menggunakan pada VLC media player, menunjukkan bahwa dalam suatu jaringan kecepatan streaming multicast pada tiap client tidak bergantung pada jumlah host atau client melainkan pada jumlah informasi yang dikirim, karena bandwidth yang diterima adalah sama. Dengan bertambahnya client yang menggunakan siaran satelit Telkom-2, 
bandwidth yang dibutuhkan tidak bertambah ataupun berkurang.

\section{KESIMPULAN}

1. Untuk membangun server multicast, server sudah terinstal sistem operasi CentOS, kemudian melakukan konfigurasi server dengan memberikan IP address pada masing-masing ethernet dan melakukan bridge interface sebagai jembatan yang menghubungkan server dengan modem Hughes.

2. Untuk melakukan konfigurasi dari sisi client agar mendapatkan streaming dari server dengan cara menginstal software VLC media player digunakan client untuk mengakses video yang di-stream dari server, dan tehubung dengan jaringan LAN AKATEL.

3. Sistem transmisi yang digunakan dalam penelitian adalah multicast, yaitu kecepatan tansmisi yang diterima client adalah sama.

\section{DAFTAR PUSTAKA}

1. Annonymous, 2009, Sejarah Centos, http://id.wikipedia.org/wiki/CentOS

2. Annonymous, TELKOM-2 "Spacecraft Controller and Operator". Orbital Propietary Foreground Data, 2005

3. Annonymous, Orbital Science Corporation, Telkom Satellite Operations Handbook, Revision A. Dulles, Virginia.

4. Askari, Azikin dan Yudha, Purwanto, 2005, Video/TV Streaming dengan
Video LAN Project, Penerbit ANDI, Yogyakarta, 152 hal.

5. Fahrial, Jaka, 2003, Teknik Konfigurasi $L A N$,

www.ilmukomputer.internux.net.id/umu m/jaka-lan.php

6. Ginting, Admar, Putra, 2008. "Layanan IPTV", Akademi Teknik Telekomunikasi Sandhy Putra Purwokerto

7. Pamungkas, Wahyu, 2007, "Diktat Kuliah Komunikasi Satelit AKATEL Sandhy Putra Purwokerto", Purwokerto, 62 hal

8. Purbo W, Onno, 1999, Komunikasi Multicast Dalam Dunia Network, http://onno.vlsm.org/v11/ref-ind1/network/komunikasi-multicast-dalamdunia-network-1999.pdf

9. Rachman, Oscar, 2008, TCP/IP Dalam Dunia Informatika dan Telekomunikasi, Penerbit INFORMATIKA, Bandung, 139 hal

10.Sopandi, Dede, 2006, Instalasi Dan Konfigurasi Jaringan Komputer, Penerbit Informatika Bandung, Bandung, 338 hal

11.Susanto, Irwan, 2007, Pedoman Penulisan Laporan Praktek Kerja Lapangan dan Penulisan Laporan Tugas Akhir, Akademi Teknik Telekomunikasi Sandhy Putra, Purwokerto 


\section{Lampiran}

Data-data yang digunakan dalam perhitungan perencanaan ini terbagi menjadi beberapa kelompok yaitu perhitungan perencanaan untuk antenna, transmitter, receiver dan radar cross section adalah sebagai berikut :
1.
Antenna :

Frekuensi

Diameter antenna

Efisiensi antenna

2. Ttransmitter \& Receiver :

Daya pancar sinyal

Gain Directivity Antenna

Jarak antenna $T x$ dengan target

Jarak antenna Rx dengan target

Loss Daya

Loss Radiasi antenna $\mathrm{Tx}$

Loss Radiasi antenna $\mathrm{Rx}$

Loss Channel 1

Loss Channel 2

Antenna Temperature

Rata-rata efektif noise temperature

Loss Receiver

Phycsical Temperature

Noise bandwidth

3. Radar Cross Section:

Surface Backscaterring Coefisien

Efektif Clutter Scattering Area

Daya Pancar Sinyal

Gain Directivity Antenna

Panjang Gelombang

Jarak yang tidak diinginkan

Total Loss

Volume backscaterring koefisien

Curah hujan rata-rata

: pengirim $(4 \mathrm{Ghz})$, penerima $(4 \mathrm{GHz})$

: pengirim $(2 \mathrm{~m})$, penerima $(5,31 \mathrm{~m})$

: pengirim $(64 \%)$, penerima $(64 \%)$

$: 150 \mathrm{Kw}$

: diperoleh dari perhitungan menu Antenna

: $20 \mathrm{Km}$

: $30 \mathrm{Km}$

$: 1.4 \mathrm{~dB}$

$: 1.2 \mathrm{~dB}$

$: 1.25 \mathrm{~dB}$

$: 1.9 \mathrm{~dB}$

$: 1.3 \mathrm{~dB}$

$: 175 \mathrm{~K}$

$: 175 \mathrm{~K}$

$: 1.614 \mathrm{~dB}$

$: 255 \mathrm{~K}$

: $10 \mathrm{MHz}$

$: 3 \mathrm{~m}^{2} / \mathrm{m}^{2}$

$: 4 \mathrm{~m}$

: $100 \mathrm{Kw}$

: diperoleh dari menu perhitungan Antenna

: diperoleh dari menu perhitungan Antenna

Cross Section Clutter : diperoleh dari menu perhitungan Cross Section Area

: $40 \mathrm{Km}$

$: 12 \mathrm{~dB}$

: $3 \mathrm{~m}^{2} / \mathrm{m}^{3}$

: $76 \mathrm{~mm} / \mathrm{hari}$

Cross section scattered : diperoleh dari menu perhitungan Cross Section Volum Target 